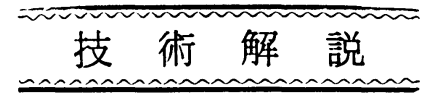

\title{
新しい塗料と塗装シリース（1）
}

古くから塗料と塗装法という言い方がある。塗料の研究は塗装性, 製膜性など塗膜自体の改良研究と, そ の塗料をいかに物体に塗布するかという塗装法の改良研究とが正に一体をなしている。しかし,「塗料」は 商品になり得ても，「塗膜」は商品になり得ない。必ず支持体である物品が存在し, その物品の美観, 耐久 性, 防せいとい5目的で塗装が行なわれる。それゆ元, 塗料側よりみた場合, 被塗物は千差万別, 下地材料 の種類が変化すれば，それに適した塗料が存在し，その塗料に適した塗装法が存在する。古くから，この側 からのアプローチが主としてなされていた。

金属材料の表面保護と美観付与法は，めっきと塗装である。言い換えれば金属製品の商品的価値を左右す るのは表面材料に負うところが大である。そして, 塗装のための表面処理も, いかにして良い塗膜を金属表 面に長期に維持するかの一手段にすぎない。

今まで, 塗料にはポリマーの塗料化の研究があり, 表面処理の研究もあった。塗装法の開発研究も進んで いる。今, 我々は環境污染の問題で多くの制約を受け, ニスト面での制約も大きい。一方，より高度の品質 の塗膜す求められ，これは互いに相反するものである。このよらな現状から，新しい技術的改良研究を総合 して判断する必要性がますます大となってきている。

在来の塗料サイドよりのアプローチは塗料メーカーにとっては必然的なものであったが，実際に塗料を使 用するサイドにとって，それは試行錯誤的に，数多くの試験品の中から良いものをみつけ出すということで あり，金属の表面処理や加工業者にとって必ずしも良いアプローチであるとは言えない。

被塗物体を十分に知るものが，その表面に適した塗料を選択し，工程に適した塗装法を採用することがで きる。特に，現在のように各技術分野の進歩が大きいとき，総合された技術としての評価をすることが強く 望まれる。塗装のための金属表面, とくに界面化学的理解, 各種塗料の製膜性とその機構, 塗膜のキュアの 方法と硬化機構などを理解し，求める被塗物に対してどのような塗料を用いれば，どのような性能があり， 経済的メリット・デメリットがあるかといら広範な知識が要望されているはずである。

本シリーズはこの観点より, 現在の技術, 研究の進歩と水準が十分に理解され, 活用されることを願って 企画されたものである。めっきを除いて，金属製品の商品化の要をにぎり，商品の品質を左右するものは塗 膜である。塗膜について深い知識を持つこともまた技術者としての必須の責務であろう。

（本誌編集委員 沖 慶雄）

\section{高分子と金属との接着メカニズムにおける 界面化学的問題点}

小 石 真 純*

複合材料の数多く出現している最近では, 接着といら “固体表面と液体あるいは固体との相互作用” の現象も 複雑化しているといえる。したがって，標題に示した内 容の議論はとてもむつかしいが，本稿では筆者の考えて いる界面化学的立場より, 一つのとら方を説明してみ たい。

高分子あるいは金属といってみても，その範囲の広い ことからすべてのポイントを記述できないであろら。そ こで, 頭の中では色材 (塗料・顔料・印刷インキ, そし て塗装など）を中心に画き，その面での参考となれば良 しとしたいと思っている。

* 東京理科大学薬学部（干162 東京都新宿区市ヶ谷船 河原町 12)

\section{1. 接着の意味づけ}

接着の過程は不可逆でなくては困る。この方向で考え ていくと，(1)材料の加工による接着の向上と(2)化学的, 物理化学的あるいは物理的な条件による接着の向上とが ある。

(1)の場合には，顕微鏡的視野での扱いで， interlocking を考える機械的接着による向上が知られている。(2) は, 界面での一次結合の形成を考える化学的接着, 静電 気的引力に基つくく接着, 固化した接着昘の粘弾的, 塑性 的変形に基づく物理的接着による向上などある。

いずれの形式をとるにしても, 接着された結果より議 論すると, 界面化学的・材料力学的・レオロジー的・材 
料的側面からの観察ができる。

Rumpfによれば1)，固体表面への固体粒子の接着機構 に関し，接着力の効果を次のように分けている。

1. without material bridges : (a) van der Waals forces, (b)electrostatics forces, (c)magnetic forces

2. with material bridges : (a) liquid bridges with mobile liquid surface, (b) viscous binding agent at points of contact, (c) solid bridges (binding agents which harden; point welding at points of contact ; sintering; crystallizing salts)

更に, “金属の表面と接着”との関係では, 次の点よ り観察されている2)。すなわち, 吸着と表面污染, 金属 表面の接着性, 表面あらさ, 表面処理などから扱ってあ る。

吸着と表面污染では，(1)銅の清浄表面に，污染物質と してステアリン酸及びオレイン酸の累積膜をつくり，累 積回数と接着はく離前後のカウント数（C ${ }^{14}$ ラベルステ アリン酸使用）及び水に対する接触角を調へ，更に累積 回数とはく離接着強さの関係を調べた結果, (2)摩擦係数 測定装置を用い， $\mathrm{Al}, \mathrm{Cu}, \mathrm{Fe}$ ，ステンレス鋼などの表面 を, オレイン酸, オクタデカンで污染し, 摩擦係数〜変 位, 污染時間 摩擦係数, 接触角 摩擦係数, 摩擦係数 〜表面被覆率などの関係を検討した結果，(3)酸化皮膜の 厚さとポリェチレンーアルミニウムのはく離強さの関係, などの研究を紹介している。

金属表面の接着性では, (1)各種金属の膨張係数と接着 強さの関係（加熱, 冷却過程に打いて接着界面に発生し た熱ひずみ力は, 金属とポリマーの膨張係数の差の小さ いほど小さくなるので，他の要因を考慮に入れなければ 接着強さは大きくなるはずである)，(2)クロム酸混液処 理及び末処理のアルミニウム粉末の, エポキシ樹脂に対 する混合率を変えた試料について, 加熱処理後のエポキ サイド含量の変化を調べた結果, アルミニウムの含量が 多くなると, エポキサイド含量は減少の傾向にあり, ア ルミニウム表面にエポキシ樹脂が結合を起こしていると 考えられる，ことなど紹介している。

更に, 表面あらさと表面処理では, 前者については特 に定量的な研究を紹介している。例えば, $\mathrm{Al} /$ 変性エポ キシの系で, せん断接着強さは, 鋭い砥粒処理>鈍い砥 粒（ガラスビーズなど）処理であり，更にサンドブラス トやショットブラストの効果は, 表面の清浄も含めて形 態学的な問題で，鋭い角や深い穴などを形成して接着阂 の充てんを容易にするなどである。後者は，その基本的 考方方として，“表面処理の効果は表面污染を除去し， 必要ならば下地金属との密着性が良く, しかも下地金属 よりも接着昘分子に対して接着性のすぐれた，強しんな 活性皮膜を形成させることにある”と指摘している。具
体的には，銅，銅合金及びスチールに対する処理法，(1) アルカリ性過マンガン酸塩による酸化，(2)アルカリ性ク ロメート浴によりクロム酸化物を電着する,などの例が 記載されている。

以上のことで，“接着の簡単な意味づけ”を行なった が，これらの中に出てくる接着に関係した keyword が のみこまれるならば，接着のファセット的側面の理解が 可能であろら。

接着理論は, 接着エネルギー及び接着力, 接着強度, 接着強度 破壊, 接着と分子間力, ぬれと接着, 接着と 化学構造, 接着とレオロジーなど多くの理論が知られて いるが,これらはここでは省略する。

\section{2. 表面粗度と接着}

固体の表面は決して平坦なものではなく，凹凸がある のでこの点に留意すべきである。例えば，機械的接着に 特ける interlocking を考えるときの凹凸の大きさは， 顕微鏡的視野のものである。しかし，もっと大きな凹凸 をつくる必要性も, 特殊なケースとしてはあるであろ 5。

単純に考えるならば, 平坦な場合の $\boldsymbol{n}$ 倍の表面積をつ くれるから，したがってぬれが十分であれば接着の仕事 も $n$ 倍になる。しかしながら，前述のことのみではかた ずけられないのが接着強度に関する結果であり，この場 合にはむしろ面の機械的清浄効果に関連するとされる。

金属表面と接着のなかでは，金属表面の粗度・熱膨張 係数の差, 金属表面への他物質の吸着などが主たる問題 点であることは，すでに指摘されたと拉りであるが，こ れに加えて表面層の性状（酸化皮膜, ベルビー層など） と金属表面のもつ自由エネルギーが関与する。

後者の 2 つことに関しては, 金属面と高分子の接着 力を考えた場合，単に金属面を検討するだけでなく高分 子の改良あ必要であろら。これについては後述する。

表 1 は, 鋼表面の凹凸, 接触角, 比接着強度の比較例 である゙っ。これは, 鋼: SAE1010のエポキシ系接着剤と の結果で, 48時間(室温), $250^{\circ} \mathrm{F}$ (3 時間) で接着され たあとのデーターである。鋼の表面処理条件と凹凸の関 係を対比すると興味がある。

\section{3. 表面処理と接着}

金属は，高エネルギー物質であり，高分子は主として 中または低ェネルギー物質である。いま，金属／高分子 の接着を考えるとき，金属の表面を中また低エネルギ一 にするか，あるいは高分子の表面を高エネルギーにすれ ばよい。

そこでここでは前述の後者のための条件と手法を中 心に説明してみよう。 
まず，いままでに考えられたことのある例を示そう。

（1）テフロン樹脂の接着面を有機チタン化合物で処理

して活性化する方法。

(2) 高分子を, $\mathrm{Al}(\mathrm{OH})_{3}$ ゾル, $\mathrm{AlCl}_{3}$ 溶液あるいはカ チオン活性刜溶液の適当濃度のものに浸せさし乾燥する ことにより(表面定着法), 高分子表面の電荷符号の調節 を行なら。これによって，被着性が向上する。

（3）クロム酸のアルカリ土類金属塩を硫酸で処理し, 沈殿を更に余分の硫酸に溶解し，その中にポリエチレン を浸せきして取り出し, 水洗して乾燥すると接着力が増 大する。

(4) ポリオレフィンをペルクロロエチレンなどの塩素 化炭化水素，トルエンなどの炭化水素に浸せさして非晶 部分, 低分子量の部分を膨潤, 抽出して, 表面に細い凹
凸をつくる前処理の方法 (micro etching)。例えば， ペ

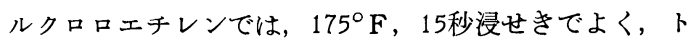
リクロルエチレンでは蒸気にさらしても同様の効果がえ られる。

（5）物理化学的に添加剤の単分子層を高分子の表面に 形成させて，高ェネルギー表面にかえる。例觉ば，内部 用帯電防止剂として, 両性界面活性剂金属塩を, ポリエ チレンに添加してやると，この場合に水に対する接触角 も著しく低下する。したがって，接着性が良くなる。

ここで, ポリェチレン，テフロン及びパラフィンなど の改質について詳しく説明してみよう

ヒドロゾルー疎水性表面系に沶ける改質の可能性が指 摘された。

低エネルギー表面をぬらすヒドロゾル類は，主として 各種金属の塩化物が使用され，

表 1 鋼表面のぬれと接着力

\begin{tabular}{|c|c|c|c|c|}
\hline & 鋼 の表面 処 理 & $\begin{array}{c}\text { 表面の凹凸 } \\
(\mu \text { in })\end{array}$ & 接触角 $\left(^{\circ}{ }^{\circ}\right)$ & $\begin{array}{c}\text { 比接着強度 } \\
(\%)\end{array}$ \\
\hline $\begin{array}{l}\text { 溶 } \\
\text { 剤 } \\
\text { 洗 } \\
\text { 浄 }\end{array}$ & $\begin{array}{l}\text { トルエン } \\
\text { ヘプタン } \\
\text { メチルエチルケトン } \\
\text { 酢酸エチル } \\
\text { トリクロルェチレン(標準) } \\
\text { メチルクロロホルム(5分) } \\
\text { 超音波洗浄(20分) }\end{array}$ & $\begin{array}{l}10 \sim 15 \\
10 \sim 15 \\
10 \sim 15 \\
10 \sim 15 \\
15 \sim 15 \\
10 \sim 15 \\
10 \sim 15\end{array}$ & $\begin{array}{l}77 \\
51 \\
47 \\
43 \\
42 \\
35 \\
34\end{array}$ & $\begin{array}{r}28 \\
93 \\
93 \\
94 \\
100 \\
110 \\
113\end{array}$ \\
\hline $\begin{array}{l}\text { 機 } \\
\text { 械 } \\
\text { 的 } \\
\text { 処 } \\
\text { 理 }\end{array}$ & $\begin{array}{l}\text { Sisal Buffing (30秒) } \\
\text { Polish (30秒) Sisal ( } 1 \text { 分) } \\
\text { Polish (1 分) } \\
\text { Buffing ( } 1 \text { 分) } \\
\text { Grit Blasting }\end{array}$ & $\begin{array}{l}5 \\
5 \\
10 \\
10 \sim 15 \\
80 \sim 100\end{array}$ & $\begin{array}{l}42 \\
42 \\
41 \\
44 \\
36\end{array}$ & $\begin{array}{l}103 \\
102 \\
108 \\
103 \\
102\end{array}$ \\
\hline $\begin{array}{l}\text { 化 } \\
\text { 学 } \\
\text { 的 } \\
\text { 処 } \\
\text { 理 }\end{array}$ & 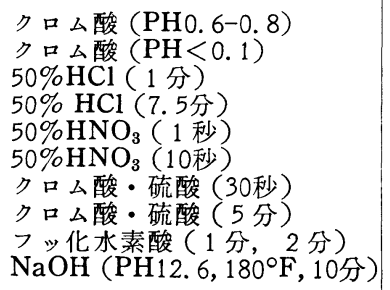 & $\begin{array}{l}10 \sim 20 \\
10 \sim 20 \\
10 \sim 20 \\
10 \sim 20 \\
10 \sim 20 \\
10 \sim 20 \\
25 \sim 30 \\
60 \sim 70 \\
20 \sim 15 \\
10 \sim 20\end{array}$ & $\begin{array}{l}42 \\
38 \\
38 \\
35 \\
38 \\
35 \\
34 \\
34 \\
29 \\
36\end{array}$ & $\begin{array}{l}110 \\
111 \\
104 \\
113 \\
115 \\
130 \\
105 \\
108 \\
112 \sim 115 \\
119\end{array}$ \\
\hline
\end{tabular}

表 $2 \mathrm{Sn}$ 及び $\mathrm{Fe}$ ゾルの性質と改質高分子の接触角

\begin{tabular}{|c|c|c|c|c|}
\hline & $\mathrm{Fe}$ 七 & ロゾル & $\mathrm{Sn} ヒ$ & ドロゾル \\
\hline 濃度 & \multicolumn{2}{|c|}{$\mathrm{Fe}$ (III) $3.7 \times 10^{-2} \mathrm{M}$} & \multicolumn{2}{|c|}{$\begin{array}{l}\text { Sn (II) } 1.6 \times 10^{-2} \mathrm{M} \\
\text { Sn (IV) } 2.9 \times 10^{-3} \mathrm{M}\end{array}$} \\
\hline pH（最終） & 1.44 & & 0.85 & \\
\hline 表面張力 $\left(23^{\circ} \mathrm{C}\right)$ & $\begin{array}{l}74.0 \pm .5 \\
\text { テフロソ }\end{array}$ & $\begin{array}{l}\mathrm{es} / \mathrm{cm} \\
\text { リチレン }\end{array}$ & $\begin{array}{l}75.0 \pm .5 \\
\text { テフロン }\end{array}$ & $\begin{array}{l}5 \text { dynes/cm } \\
\text { ポリエチレン }\end{array}$ \\
\hline $\begin{array}{l}\text { 浸せき時間（分） } \\
\text { デボジット量（金属と }\end{array}$ & 16.0 & 2.0 & 7.5 & 0.25 \\
\hline $\begin{array}{l}\text { して） } \mu \mathrm{g} / \mathrm{cm}^{2} \\
\text { （接触角） }\end{array}$ & 3.33 & 0.20 & 0.68 & 0.22 \\
\hline 後退, 未処理 & $101^{\circ} \pm 3^{\circ}$ & $67^{\circ} \pm 1^{\circ}$ & $101^{\circ} \pm 3^{\circ}$ & $67^{\circ} \pm 1^{\circ}$ \\
\hline 後退, 処 理 & $0^{\circ}$ & $0^{\circ}$ & $0^{\circ}$ & $0^{\circ}$ \\
\hline 前進, 未処理 & $105^{\circ} \pm 2^{\circ}$ & $88^{\circ} \pm 1^{\circ}$ & $105^{\circ} \pm 2^{\circ}$ & $88^{\circ} \pm 1^{\circ}$ \\
\hline 前進, 処 理 & $54^{\circ} \pm 2^{\circ}$ & $68^{\circ} \pm 2^{\circ}$ & $32^{\circ} \pm 1^{\circ}$ & $39^{\circ} \pm 2^{\circ}$ \\
\hline
\end{tabular}
とさに硝酸塩が用いられた。実 験では, $\mathrm{Be}, \mathrm{Mg}, \mathrm{Ti}, \mathrm{Zr}, \mathrm{V}$, Cr, Mo, W, Mn, Fe, Co, Ir, $\mathrm{Ni}, \mathrm{Pd}, \mathrm{Pt}, \mathrm{Cu}, \mathrm{Ag}, \mathrm{Au}, \mathrm{Zn}$, $\mathrm{Cd}, \mathrm{Hg}, \mathrm{Al}, \mathrm{Ga}, \mathrm{In}, \mathrm{Tl}, \mathrm{Si}$, $\mathrm{Ge}, \mathrm{Sn}, \mathrm{Pb}, \mathrm{As}, \mathrm{Sb}, \mathrm{Bi}, \mathrm{Ce}$, $\mathrm{Th}, \mathrm{U}, \mathrm{La}$ などのゾルが使用 されたが，Fe とnゾルのみ が，ポリエチレン，テフロン， パラフィンの表面を改質でき た。な拉, ゾルの $\mathrm{pH}$ と濃度が 主因子で，このコントロールが 重要であった。

表 2 は，Sn及び Feゾルの性 質とテフロン，ポリエチレンの 改質による接触角值の変化であ る。

接触角値の変化よりわかるよ らに, ポリエチレンやテフロン の表面エネルギーの増加は，そ れら表面へのコロイド状 $\beta-\mathrm{Fe}$ $\mathrm{OOH}$ または含水スズ酸化物の デポジションによるといえる。 コロイド粒子の高分子表面への 付着は, 洗浄後において子確か められるが，この確認は以下の ことでなされた。

(a) 付着コロイド粒子は, 超 音波洗浄，空気または水ジェッ トによる処理などでも, 高分子 表面より除去されない。

（b）付着コロイド粒子は，接 着テープによっても除去できな 
い。スコッチ No. 810 接着テープを, 洗浄後に乾燥した コロイド処理テフロンにプレスしたのち，はがしたとこ ろコロイドデポジットはテープ上に除去されなかった。

表 2 には示してないが，パラフィンの場合にもその表 面に $\beta-\mathrm{FeOOH}$ がデポジットされる。 Fe ヒドロゾルに 30分間浸せきすると, $34 \mu \mathrm{g} / \mathrm{cm}^{2}$ の鉄がデボジットされ, 66時間後には $58 \mu \mathrm{g} / \mathrm{cm}^{2}$ になで増加する。これらのゾル も決して除去されない。

な拉，これらのコロイドはエポキシ，ポリエステル，

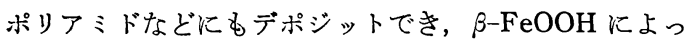
てそれらの表面が親水化できる。

さて, 表 2 亿示したような後退接触角のゼ口値は, こ れらヒドロゾル処理表面に対して, 次の液体によっても 観察された。

極性液体（クロルニトロベンゼン，ジメチルスルホキ シド, ジメチルホルムアミド, アセトン, 1, 1,1-トリク ロルェタン), 非極性液体 (ベンゼン, ヘキサン, 四塩 化炭素) 及び水素結合液体（水, メタノール, エタノー ル)

このことから, 液体の溶解性パラメーターによる効果 は認められず，ヒドロゾル処理表面は高ェネルギー表面 になったと推論できる。

$\mathrm{Fe}$ ヒドロゾルの性質は, $\mathrm{pH}$ 及び鉄イオン濃度によっ てかわるが，図１は高分子の良好な改質が可能な条件を 示したものである。 $\beta-\mathrm{FeOOH}$ は $\mathrm{pH} 1.50$ では針状結晶 (0.1 $\mu$ 程度の長軸径), $\mathrm{pH} 1.25$ では 6 角板状結晶 (0.5 径)である。これらの結晶の大きさが関係するのではな かろらか。つまり, テフロンまたはポリエチレンの表面 飞は数多くの空孔とか凹凸が存在するので，この中にヒ ドロゾルが浸透する。その可能性が， $\mathrm{pH}$ 1.50でのヒド ロゾルにあるといえる。しかし，つづいて行なわれる洗 浄操作があると，ヒドロゾルは再び洗出されることにな るのだが，幸いなことに $\mathrm{pH}$ 3.0以上ではヒドロゾルはフ ロキュレーションを起こし, 沈殿物となる。この沈殿物 は恐らく空孔や凹内にかなり残るのではないだろらか。 そらでないと高分子表面の改質は考光にくい。いま，仮 に $\mathrm{pH}$ 3. O以上のフロキニレートの存在下で, 高分子を浸 せきしてもその表面は改質されないであろう。

以上の実験例からも理解されるように，ヒドロゾルの 工業利用は極めて重要である。

テフロンの改質の試みは，その臨界表面張力 $\gamma_{c}$ の小 さいことより多くの面で興味があるといわ秝ばならな

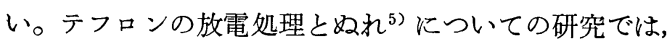
放電処理によって生ずるテフロン表面の変化を次のよう に考兄ている。すなわち，

(i) 表面の化学的な組成が变化する。

（ii）表面層の結晶化度あるいはカ橋度が变化す

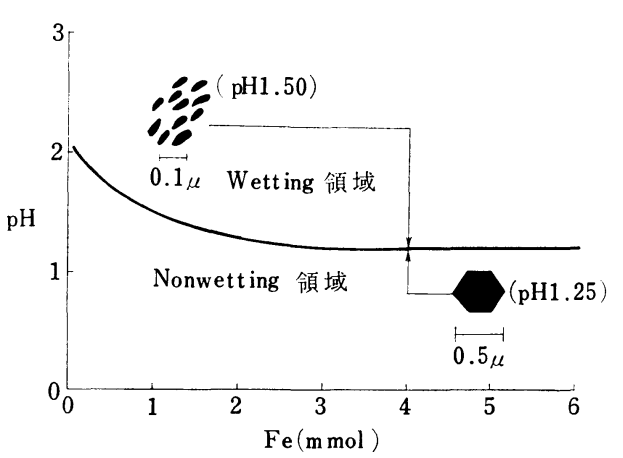

図 $1 \mathrm{Fe}$ ヒドロゾルの $\mathrm{pH}$ 及び鉄濃度の関数として の高分子のぬれ特性

(注) $\mathrm{Fe}(\mathrm{m} \mathrm{mol})$ は, $\mathrm{Fe} \mathrm{Cl}_{3} \cdot 6 \mathrm{H}_{2} \mathrm{O}$ としての值 อ。

（iii）表面の幾何学的形態が変化する。

$r l \operatorname{Cos} \theta$ の関係， $\gamma_{c}$ の変化などの検討結果はさて拉 いて，このような变化を与えた表面に前述のヒドロゾル をデポジットさせると極めて興味のある表面が可能であ ろら。

プラスチック表面の活性化については，いろいろの方 式のあることが知られているので6)，前述のヒドロジル の活用はこれからの一つの方向性であると推論される。

活性ガスによる色材の表面処理では7，（1)高周波誘導 加熱によるプラズマジェット処理，(2)コロナ放電処理, (3)拘束アーク放電によるプラズマジェット処理などある が，これらの処理を利用するのも良い。

\section{4. 表面処理における着想と接着 技術への可能性}

砂, 鋼砕粒(Grit), カーボランダムなどによる高分子 の表面の粗面化(Roughening) は, 塗装, めっき, 接着 などの前処理として, 金属におけると同様に行なわれて いる。この効果は投錨効果, interlocking 効果などであ る。

このような前処理では, 高分子の表面が粗面化される だけでなく，その表面に処理剤の超微粉が吸着されてい るはずである。したがって，高エネルギー表面に近づく 可能性がある。

いま，前述と同様のことを以下の方式で試み，特殊な 表面性質の粉体をつくり，これを高分子にブレンドした とすると, いわゆる従来からいわれている充てん材と異 なって興味がある。

実験には, 立型の遠心回転ボールミル（図 2参照）が 使用される。実験条件の例は次のと扣りである ${ }^{8)} 。$

図 2 中の円板 (直径 $200 \mathrm{~mm}$ ) A上に, アルミナボール （直径 $6 \mathrm{~mm}$ ）を 7,750個（容器内容積 4,000 $\mathrm{ml}$ の1/3容 積に相当）のせ, 更にカオリン $172 \mathrm{~g}$ と水 $230 \mathrm{ml}$ を加え 


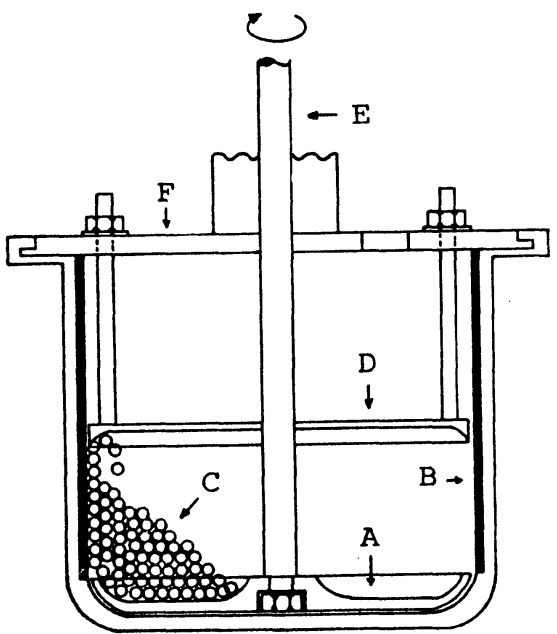

図 2 遠心回転型ボールミル

(注) A : 円板, B : ライニング壁（ステンレススチ ール SUS-304), C：アルミナボール, D : ジャマ板, $\mathrm{E}:$ シャフト, F：フタ。

る。円板 Aは230，350，500または650rpm で回転でき

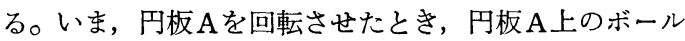
群Cとカオリン懸濁液は遠心力によって外側に押し出さ れる。この際, 回転軸Eからもっとも遠いボール群から 順にステンレススチール(SUS-304)でライニングされた 壁面Bに押しつけられる。この外側のボール群はつづい て押しつけられてくるその内側のボール群によって押し 上げられ壁面Bに沿って登りはじめる。ジャマ板Dに到 達したボール群は, ジャマ板の曲率によって内側に押し 戻され重力によって落下し, 再びボール群Cに戻る。こ のような挙動中に, ボール群及びカオリン粒子は, ステ ンレススチール板を湿式条件下で切削・はく離させる。 また同時にカオリン自体もボールによる衝撃によって摩 砕される。

カオリンの摩砕の進行と同時に, 切削・はく離された ステンレススチール超微粉は，カオリン表面に物理吸着 する。したがって，カオリンの色調は白色より扊色にな る。ステンレス改質の程度は, ゼータ電位の值の変化よ りわかるが9)，これはカオリンが約－100mVの電荷を有 しているのに対し，ステンレス粉は＋50mVの電荷を示 すことに起因する。つまり，摩砕時間の増加とともにゼ ータ電位が負の值でゼロに近いステンレス改質カオリン 粉体が得られる。

X線マイクロアナライザーによる改質カオリンの表面 観察によれば，ステンレススチール超微粉が均質にカオ リソ表面に吸着されたことが確認される。

カオリンの代りに各種の粉体を用いても前述と同様の ことは可能であろう。また，ステンレススチールの代り に他の金属パネルをライニングしても良い。この得られ
た粉体の表面は金属超微粉であるから; 高分子の充てん 材として添加したさいに単に混合された金属粉とは, 異 なった挙動を示すであろう。また, 各種の前処理に対し ても従来とは形式を異にした高分子表面が得られると考 える。

メカノケミカルな反応については, いくつかの目的が 知られているが，メカノケミカル研摩・粉体の表面改質 の簡易化，金属粉の摩砕による焼結性の向上などはその 工業的応用例である ${ }^{10)} 。$

接着に扣いて，金属表面や高分子表面をあらかじめ機 械的に処理することは，それらに格子欠陷・格子不整を 発生させるか，あるい情面エネルギー・比表面積・結 晶化度などを相違させることにあるから，得られた状態 の活用は十分に考学る必要がある。ステンレス改質一カ オリン粉体はこの点に着目している。

\section{あとがき}

高分子と金属との接着メカニズムに括ける界面化学的 問題点を，一つの側面よりまとめてみた。しかしなが ら, 本稿では接着メカニズムそのものは取上げる機会を 失ったように思われる。それは，標題の大きすぎたこと によるのかもしれないが，それと同時に接着剤の果たす 役割が大きいことを意識しすぎたためかもわからない。 いずれにしても不十分なところが多い点は御容捨願いた W。

最後に,ここでは詳細な紹介をしなかった研究や総説・ 解説を下記に示しておく。

（1）工業材料，24，[5]，（1976）“特集 プラスチッ クのメタライジング"

（2）工業材料，24，[8]，（1976）“特集 金属の接着”

(3) 工:業材料, 20，[12]，（1972）“接着不良対策ハン ドブック”

(4) J.R. Dann; Forces Involved in the Adhesive Process. I. Critical Surface Tensions of Polymeric Solids as Determined with Polar Liquids, J. Colloid \& Interface Sci., 32, [2], 302(1970)

(5) J. R. Dann ; Forces Involved in the Adhesive Process. II. Nondispersion Forces at Solid-Liquid Interfaces, J. Colloid \& Interface Sci., 32, [2], 321 (1970)

(6) H.G. Bruil and J.J.van Aartsen; The Determination of Contact Angles of Aqueous Surfactant Solution on Powders, Colloid \& Polymer Sci., 252, 32 (1974)

（7）岡昭夫；ふっ素樹脂のコーティングとライニング (1)，(2)，塗装の技術，7，[7]，10(1972)，7，[9], 22 (1972) 


\section{文献}

1) H. Rumpf ; Adhesion of Solid Particles on Solid Surfaces, 粉体工学研究会誌, 9, 秋季臨時号, 3 (1972)

2）福村勉郎; 金属の表面と接着, 工業材料, 24, [8] 23 (1976)

3) 丸茂秀雄 ; 高分子の表面化学, p. 81 (1968, 産業図 書)

4 ) J.T. Kenney, W.P.Townsend, and J.A.Emerson ;

J. Colloid \& Interface Sci., 42, (3), 589 (1973)

5 ）角田光雄, 大場洋一, 千葉克義, 福村勉郎; テフロ ンの放電処理, 工化誌, 71，1692（1968）

6) 小石真純；プラスチック表面の活性化, 工業材料,
17, (2), 16 （1969）小石真純, 角田光雄 ; 粉体の表面 化学, p. 53 (1975, 日刊工業新聞社)

7 ）北小路俊右，村川恭平；活性ガスによる色材の表面 処理, 色材, 47, 125 (1974) 小石真純 ; プラズマ加 熱による粉体の調製, 47,121（1974）松本修; プラズマ 化学とその応用, その現状と将来性, 色材, 47, 112 (1974)

8 ）武林敬, 小石真純；ステンレス改質一カオリン 粉体 の調製とその性質，色材，49，277（1976）

9) 武林敬, 小石真純; ゼータ電位によるステンレス改 質一カオリン粉体の評価, 色材, 49, 480 (1976)

10) 化学工学協会編; 最近の化学工学, 特殊粉体技術, p. 60 (1975, 丸善)

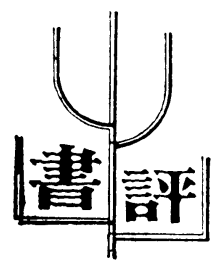

技術とそれを取り巻く環境がめまぐるしく変化する今 日，基礎だけを扱う教科書ならばともかく，先端技術を 含めてこのような便覽を集大成することは非常に難しい 仕事に違いない。もてはやされた技術が公害問題で影を ひそめ，流行からとり残されたように顧みられなくなっ た測定法もあったりするからである。昭和38年の改訂版 から10年以上を経た現在，すべての技術をるららすると すれば，旧版の倍の厚さになるであろう。浅原便覧編集 委員長を中心とする委員・執筆者の方々の賢明な取捨選 択によって旧版を下回る厚さで注とんどすべての金属表 面技術のエッセンスが盛り込まれていることは, 利用者 にとってまことに有り難い。

改訂新版ではイオンプレーティング, プラスチックメ ッキ, 複合メッキ, 粉体及び電着叙装, 排ガス処理技 術, その他多くの新しい技術が随所に加えられている。 したがって, 新版は值段が高いから当分旧版で我慢しよ らなどとは言っていられない。会員特価と旧版の下取り 制度もあるので，この際入手して招かれるのが得策であ ろら。各専門分野ではそれぞれより詳しい便覧, 例えば 「めっき技術便覧」「アルミニウム加工技術便覧」など
もあるが，金属表面技術のすべてを含めた一冊の便㰖 は，自分の専門外の知識を得るためにる便利で，なくて はならないるのである。

周到綿密な編集に利用者として讃辞を惜しまないが， 書評なので少し欲を言わせていただこう。技術の基礎と なる「表面とは何か」の解説が余りにも短い。各処理法 がそれぞれ独立のものとして扱われているが，機能別に 各技術を眺めるという考方方もるら少し強く打ち出して すよかったのではないだろらか。「耐摩耗性の表面を得 るにはどんな方法があるのか」といら利用者のニーズに ずばり答えられるような一。細かい点では, 同一文献 からの 3 つの走査電子顕微鏡写真が別の章で重複して載 っているのが気になり, 表面検査法にエリプソメトリー やオージェ電子スペクトロスコピーなどの記述がないの も淋しい。それからもら一つ, 本誌では文部省学術用語 集化学編の増訂に伴って従来の「メッキ」を「めっき」, 「カタサ」を「硬さ」と書くことにしているが，便覧で は過渡的に「メッキ」「かたさ」となっていることを注 意して抗こう。

村川亭男 (昭和電工) 